\title{
ADOPSI NILAI KEARIFAN LOKAL DALAM KINERJA KEPOLISAN DAERAH PROVINSI LAMPUNG
}

\author{
${ }^{1}$ Simon Sumanjoyo Hutagalung, ${ }^{2}$ Tulfah H. Al Halim \\ Jurusan Administrasi Negara FISIP Universitas Lampung \\ Email: \\ ${ }^{1}$ simon.sumanjoyo@fisip.unila.ac.id, ${ }^{2}$ tulvahafiyeralhalim@yahoo.com
}

\begin{abstract}
In order to optimizing its performance, regional police of Lampung used cultural approach as a problem solving. This research intend to analyze how is the performance of regional police Lampung with the presence of that adoption and describe the stages of adoption of local wisdom. The type of this research is descriptive research with qualitative approach. The primary data was collected from the result of interview and observation, while the secondary data was collected from documents such as the decree of featured programs by the chief of regional police Lampung which included program that has been adopted from local wisdom of Lampung. The researcher has found the stages of adoption of local wisdom in the performance of regional police Lampung; a) Awareness stage, b) Interest stage, c) Assessment stage, d) Eksperiment stage, and e) Adoption stage. However, the performance of regional police Lampung considered good enough and quite able to decreasethe number of crimes in Lampung, although they are still working hard to optimalize the process of reducing a crime in Lampung.
\end{abstract}

Key words: Adoption; Local Wisdom; Performance

\section{PENDAHULUAN}

Polisi merupakan aparat negara yang memiliki tugas utama menjaga keamanan dan ketertiban masyarakat. Keberadaan kepolisian secara konstitusi diatur dalam Undang Undang Dasar 1945 Pasal 30 Ayat 4 yang menyatakan bahwa Kepolisian Negara Republik Indonesia sebagai alat negara yang menjaga keamanan dan ketertiban masyarakat bertugas melindungi, mengayomi dan melayani masyarakat serta menegakkan hukum. Pihak kepolisian mendapatkan posisi yang sangat penting bagi masyarakat. Oleh karena itu, kinerja kepolisian dituntut untuk dapat optimal.

Kinerja Kepolisian Negara Republik Indonesia (POLRI) yang dianggap baik oleh masyarakat yaitu dalam hal penanganan terorisme. Contohnya dalam aksi terorisme di Sarinah, Jakarta Pusat tahun 2015, penanganan dari pihak POLRI sangat cepat hanya dengan kurang dari empat jam saja
POLRI dapat menangani aksi terorisme tersebut. Hal ini sangat diapresiasi oleh masyarakat Indonesia dan juga diapresiasi oleh Kepala Badan Intelejen Negara (BIN) atas kesigapan POLRI dalam mengatasi aksi serangan teroris yang terjadi di kawasan Sarinah, Jakarta Pusat.

Namun kelebihan dari kinerja kepolisian masih lebih sedikit daripada kekurangannya. Sebagian besar masyarakat Indonesia menilai kinerja kepolisian masih banyak kekurangannya daripada kelebihannya. Banyak dari kaum politisi yang berpendapat bahwa kondisi POLRI saat ini berada di posisi gelap karena terlalu banyak kekurangannya sehingga menimbulkan cap hitam bagi POLRI. Sekalipun ada praktik dan perilaku polisi yang bagus, namun jumlah dan frekuensinya terlalu sedikit.

Kinerja POLRI bahkan mendapatkan rapor merah dari Indonesian Police Watch (IPW). Pada tahun 2014, kinerja POLRI dinilai 
sangat tidak memuaskan masyarakat. Reformasi kepolisian sebagai pelindung, pengayom, dan pelayan masyarakat juga jalan ditempat. Padahal di tahun 2014 POLRI memiliki sebanyak 420.275 personel disertai anggaran Rp.44,5 triliun. Sehingga POLRI mendapat rapor merah dari IPW. Hal tersebut terjadi karena integritas, keteladanan, profesionalisme dan kemitraan masih sangat lemah dan tidak ada kemajuan sama sekali di tahun 2014. Selain itu, citra kepolisian dinilai buruk oleh masyarakat. Sebagian masyarakat tidak lagi percaya dengan aparat kepolisian. Bahkan polisi bukan sebagai pelindung bagi masyarakat namun justru ditakuti atau bahkan sampai dijadikan momok bagi masyarakat.

Pada wilayah Provinsi Lampung, kinerja kepolisian juga masih dapat dinilai kurang baik. Tingginya angka kriminalitas yang ada sampai-sampai membuat citra Daerah Lampung kian memburuk belakangan ini karena aksi pembegalan yang terjadi di beberapa kota yang sebagian besar pelaku pembegalannya berasal dari Daerah Lampung. Keberadaan dan kondisi polisi adalah cermin keadaan masyarakat. Jika masyarakat maju dan kuat, polisi juga kuat. Sebaliknya, dalam kondisi masyarakat yang lemah, kelemahan polisi juga tampil dominan di Indonesia.

Baik buruknya kinerja kepolisian salah satunya dipengaruhi oleh pempimpin, dalam hal ini yaitu Kapolda. Apabila kepemimpinan dari kepala kepolisian baik, maka kinerja kepolisian juga dapat dinilai baik pula. Begitupun sebaliknya, jika kepemimpinan dari kepala kepolisian buruk maka kinerja kepolisian dapat dinilai buruk pula. Seorang pemimpin memiliki strateginya masingmasing untuk mencapai tujuan dari kepolisian. Maka di setiap kepemimpinan kepolisian pasti memiliki hasil yang berbedabeda dalam kinerjanya.
Seperti kepemimpinan dari Kepala Kepolisian Daerah Lampung yaitu Brigjen Pol Ike Edwin yaitu Kapolda Brigjen Ike Edwin dalam masa kepemimpinannya memiliki tagline PIIL. PIIL merupakan singkatan dari Profesional, Integritas, Iman, dan Law enforcement. Tagline PIIL ini diangkat dari falsafah piil pesenggiri. Dimana piil pesenggiri merupakan nilai kearifan lokal Daerah Lampung. Dalam kepemimpinan Brigjen Pol Ike Edwin menggunakan pendekatan budaya dalam mengatasi permasalahan yang ada di Daerah Lampung. Pendekatan budaya tersebut seperti nilai kearifan lokal Lampung yaitu piil pesenggiri dan juga anjau silau.

Piil pesenggiri merupakan falsafah hidup orang Lampung. Piil artinya perilaku, dan pesenggiri maksudnya bermoral tinggi, berjiwa besar, tahu diri, tahu hak dan kewajiban. Piil pesenggiri merupakan potensi sosial budaya daerah, memiliki makna sebagai sumber motivasi agar setiap orang dinamis dalam usaha memperjuangkan nilai-nilai positif, hidup terhormat dan dihargai di tengahtengah kehidupan masyarakat. Dalam hal tingginya tingkat kriminalitas di Daerah Lampung, nilai keari lokal yang diadopsi dalam kinerja kepol n Daerah Lampung adalah anjau silau. Anjau silau yang berarti saling datang mengunjungi untuk menjalin komunikasi. Salah satu program Kapolda yaitu anjau silau ini bertujuan untuk dapat menampung masalah-masalah yang diresahkan masyarakat dan untuk mencegah terjadinya konflik sosial khususnya menurunkan tingkat kriminalitas yang tinggi.

Nilai memiliki arti penting dalam kepemimpinan. Nilai-nilai kepemimpinan merupakan sejumlah sifat-sifat utama yang harus dimiliki seorang pemimpin agar kepemimpinannya dapat efektif dan efisien untuk mencapai tujuan yang telah ditentukan. Beberapa nilai kepemimpinan yang perlu dimiliki seorang pemimpin antara lain yaitu integritas, moralitas, tanggungjawab, visi 
pemimpin dan kebijaksanaan. Nilai berperan sebagai pembentuk karakter pada seorang pemimpin dalam memimpin sebuah organisasi untuk mencapai tujuan organisasinya tersebut. Seperti contohnya arti penting nilai dalam kepemimpinan kepolisian.

Pada daerah Lampung sendiri, nilai budaya yang ada sangat beragam. Nilai budaya Lampung yang ada yaitu seperti sakai sambayan, yang berarti gotong royong saling tolong menolong. Lalu piil pesenggiri, yang maknanya harga diri, perilaku dan sikap hidup. Nengah nyappur, yang artinya membuka diri dalam pergaulan. Juga bejuluk beadek, yaitu saling menghormati (Yulianto, Mulyana, \& Hutagalung, 2017). Seperti yang sudah diuraikan, dalam kepemimpinan Kepolisian Daerah Lampung, nilai budaya yang diadopsi yaitu piil pesenggiri.

Adapun rumusan masalah dalam penelitian ini yaitu; (1). bagaimana penerapan bentuk-bentuk adopsi nilai kearifan lokal dalam kinerja kepolisian Lampung?, (2). bagaimana kinerja kepolisian Lampung dengan adopsi nilai kearifan lokal tersebut?

Guna menganalisis rumusan masalah tersebut perlu dipahami konsepsi tentang adopsi nilai kearifan lokal dan kinerja. Secara konsepsi adopsi adalah proses perubahan perilaku yang berupa pengetahuan (cognitive), sikap (affective), dan keterampilan (psikomotoric) pada diri seseorang setelah menerima pesan yang disampaikan oleh orang lain seperti seorang penyuluh kepada sasarannya. Untuk mengadopsi suatu inovasi memerlukan jangka waktu tertentu dari mulai seseorang mengetahui pesan tersebut, memahami, memikirkan dan mempertimbangkan sampai terjadinya adopsi (Mardikanto, 1993).

Kemudian dinyatakan oleh Rogers bahwa perubahan seseorang untuk mengadopsi suatu perilaku yang baru tersebut terjadi dalam beberapa tahapan sebagai berikut: 1) Tahap kesadaran (awareness), dalam hal ini mulai sadar tentang adanya sesuatu yang baru, mulai terbuka akan perkembangan dunia luarnya, sadar apa yang sudah ada dan apa yang belum. 2) Tahap minat (Interest), tahap ini ditandai oleh adanya kegiatan mencari keterangan-keterangan tentang halhal yang baru diketahuinya. 3) Tahap penilaian (Evaluation), setelah keterangan yang diperlukan diperoleh, mulai timbul rasa menimbang-nimbang untuk kemungkinan melaksanakannya sendiri. 4) Tahap mencoba (Trial), jika keterangan sudah lengkap, minat untuk meniru besar, dan jika ternyata hasil penilaiannya positif, maka dimulai usaha mencoba hal baru yang sudah diketahuinya. 5) Tahap adopsi (Adoption), sudah mulai mempraktekkan hal-hal baru dengan keyakinan akan berhasil (Rogers, 1983).

Nilai adalah suatu tatanan yang dijadikan panduan oleh individu untuk menimbang dan memilih alternatif keputusan dalam situasi sosial tertentu. Kepribadian manusia terbentuk dan berakar pada tatanan nilai-nilai kesejarahan. Meskipun menempatkan konteks sosial sebagai dimensi nilai dalam kepribadian manusia, namun hal tersebut diakui sebagai kekuatan individual yang dikenal dengan istilah roh subjektif. Sementara itu, kekuatan nilai-nilai kebudayaan merupakan roh objektif. Kekuatan individual atau roh subjektif didudukkan dalam posisi primer karena nilainilai kebudayaan hanya akan berkembang dan bertahan apabila didukung dan dihayati oleh individu (Suryabrata, 1998). Nilai ini kemudian yang mempengaruhi upaya pembangunan di masyarakat, dimana salah satu sumbernya adalah dari kearifan lokal (Suswanto et all, 2015).

Kearifan lokal adalah semua bentuk pengetahuan, keyakinan, pemahaman atau wawasan serta adat kebiasaan atau etika yang menuntun perilaku manusia dalam 
kehidupan di dalam komunitas ekologis. Setiap wilayah tentu memiliki budayanya sendiri dengan berbagai kearifan di dalamnya (Suwardani, N. 2015). Jadi kearifan lokal ini bukan hanya menyangkut pengetahuan dan pemahaman masyarakat adat tentang manusia dan bagaimana relasi yang baik di antara manusia, melainkan juga menyangkut pengetahuan, pemahaman dan adat kebiasaan tentang manusia, alam dan bagaimana relasi di antara semua penghuni komunitas ekologis ini harus dibangun. Seluruh kearifan tradisional ini dihayati, dipraktikkan, diajarkan dan diwariskan dari satu generasi ke generasi lain yang sekaligus membentuk pola perilaku manusia sehari-hari, baik terhadap sesama manusia maupun terhadap alam dan yang gaib (Keraf, 2010).

Kinerja adalah bagaimana seseorang diharapkan dapat berfungsi dan berperilaku sesuai dengan tugas yang telah dibebankan kepadanya. Setiap harapan mengenai bagaimana seseorang harus berperilaku dalam melaksanakan tugas, berarti menunjukkan suatu peran dalam organisasi (Sutrisno, 2011). Kinerja adalah tingkat pelaksanaan tugas yang dapat dicapai seseorang, unit atau divisi dengan menggunakan kemampuan yang ada dan batasan-batasan yang telah ditetapkan untuk mencapai tujuan organisasi (Samsudin, 1982). Kinerja juga dapat dimaknai sebagai kuantitas, kualitas, dan waktu yang digunakan dalam menjalankan tugas. Kuantitas adalah hasil yang dapat dihitung sejauh mana seseorang dalam menjalankan tugasnya, yaitu mengenai banyaknya kesalahan yang dibuat, kedisiplinan dan ketepatan. Waktu kerja adalah mengenai jumlah absen yang dilakukan, keterlambatan, dan lamanya masa kerja dalam tahun yang telah dijalani (Sutrisno, 2011).

\section{METODE PENELITIAN}

Penelitian ini menggunakan metode deskriptif dengan pendekatan kualitatif.dengan fokus penelitian ini adalah:

1. Lima tahapan adopsi dari adopsi nilai kearifan lokal pada kinerja kepolisian daerah Lampung menurut Rogers (1983), yaitu:

a. Tahap kesadaran (awareness), dalam hal ini pemimpin (Kapolda) mulai sadar tentang adanya sesuatu yang baru dan sadar akan apa yang sudah ada maupun yang belum.

b. Tahap minat (interest), ditandai dengan adanya kegiatan mencari keterangan tentang hal seperti nilai kearifan lokal yang diketahuinya.

c. Tahap penilaian (evaluation), mulai muncul rasa menimbang-nimbang untuk kemungkinan melaksanakan-nya sendiri.

d. Tahap mencoba (trial), memulai usaha mencoba hal tersebut.

e. Tahap adopsi (adoption), sudah mempraktekkan nilai kearifan lokal pada kinerja pegawai dengan keyakinan akan berhasil.

2. Kinerja kepolisian Daerah Lampung setelah adanya adopsi nilai kearifan lokal tersebut. Adapun metode penilaian kinerja menurut Robbins (2001) adalah:
a) Penilaian performansi berdasarkan hasil (result-based performance evaluation)
b) Penilaian performansi berdasarkan perilaku (behavior based performance evaluation)
c) Penilaian performansi berdasarkan
judgement (judgement-based performance
evaluation)

Pengumpulan data dilakukan melalui observasi, wawancara dan dokumentasi. Analisis data melalui tiga tahap yaitu reduksi data, penyajian data, dan penarikan kesimpulan. 
HASIL DAN PEMBAHASAN

\section{Lima Tahapan Adopsi dari Nilai Kearifan Lokal Pada Kinerja Kepolisian Daerah Provinsi Lampung}

\section{Tahap Kesadaran (Awareness)}

Dalam tahap kesadaran pada adopsi nilai kearifan lokal rembuk pekon yang digagas oleh Brigjen Pol Heru Winarko didasari oleh keadaan yang mendesak beliau untuk berinovasi dalam rangka mengoptimalkan kinerja Kepolisian Daerah Provinsi Lampung. Hal mengenai rembuk pekon bukanlah sesuatu yang baru di masyarakat Lampung. Dengan adanya kunjungan Brigjen Pol Heru Winarko ke 14 kota dan kabupaten selain mengunjungi Polres di masing-masing daerah, beliau juga bertemu dengan tokoh-tokoh masyarakat di berbagai daerah tersebut. Kegiatan tersebut juga berlangsung pada saat masih terjadinya konflik sosial yang sedang marak terjadi.

Hal tersebut menjadi buah dari kesadaran Brigjen Pol Heru Winarko dalam tercetusnya ide rembuk pekon. tahap kesadaran dalam adopsi nilai kearifan lokal falsafah piil pessenggiri yang dituangkan dalam tagline PIIL oleh Brigjen Pol Ike Edwin diawali dengan munculnya kesadaran beliau bahwa budaya merupakan hal yang baik. Serta disadari pula oleh buruknya citra dari Kepolisian Daerah Provinsi Lampung dimata masyarakat. Beliau melihat adanya kesenjangan antara masyarakat dan pihak kepolisian, bahwa masyarakat kurang menyukai perilaku dari oknum-oknum kepolisian. Brigjen Pol Ike Edwin menilai bahwa mungkin oknum kepolisian tersebut tidak memahami tentang adat, sopan santun dan budaya yang berkembang di masyarakat Lampung.

Kemudian dengan kesadaran tersebut beliau mengharapkan perubahan dari perilaku pihak kepolisian untuk lebih baik. Sehingga citra buruk dari kepolisian yang memang sudah ada di masyarakat akan berubah menjadi baik. tahap kesadaran dari Brigjen Pol Ike Edwin yang mengadopsi nilai kearifan lokal falsafah piil pessenggiri hampir sama dengan Rogers yang dalam tahap ini sadar tentang adanya sesuatu yang baru, mulai terbuka akan perkembangan dunia luarnya, dan sadar akan apa yang sudah dan yang belum.

Pada tahap ini Brigjen Pol Ike Edwin menyadari bahwa adanya citra buruk dari perilaku Kepolisian Daerah Provinsi Lampung dan beliau mulai mencoba menyisipkan sesuatu yang baik dalam kinerja Kepolisian Daerah Provinsi Lampung guna mengubah citra buruk dari masyarakat terhadap organisasi yang dipimpinnya. tugas kepolisian yang diatur dalam UndangUndang Dasar 1945 Pasal 30 ayat 4 yang menyatakan bahwa Kepolisian Negara Republik Indonesia sebagai alat negara yang menjaga keamanan dan ketertiban masyarakat bertugas melindungi, mengayomi dan melayani masyarakat serta menegakkan hukum. Jadi dapat disimpulkan bahwa jika pandangan masyarakat terhadap kepolisian buruk, maka tugas atau fungsi kepolisian sebagai pelindung, pengayom dan pelayan masyarakat dan penegak hukum dapat dianggap gagal.

\section{Tahap Minat (Interest)}

Pada tahap minat, dengan adanya kesadaran bahwa budaya itu baik dan nilai kearifan lokal khusunya pada nilai kearifan lokal Lampung merupakan hal yang baik, maka Kapolda Lampung mulai menggali informasi yang lebih mendalam mengenai nilai dan kebudayaan Lampung. Menurut Rogers pada tahap minat (interest) ini ditandai oleh adanya kegiatan mencari keteranganketerangan tentang hal-hal yang baru diketahuinya. Sedikit berbeda dengan Rogers, tahap minat dalam adopsi nilai kearifan lokal rembuk pekon oleh Brigjen Pol Heru Winarko dilakukan bersamaan dengan tahap 
kesadaran (awareness). Beliau menggali informasi mengenai rembuk pekon yang didapatkannya oleh tokoh-tokoh masyarakat yang ditemuinya pada saat kunjungan ke 14 kota dan kabupaten. Beliau mendapatkan banyak masukan dari tokoh masyarakat tersebut mengenai pentingnya rembuk pekon dalam mengatasi konflik sosial yang pada saat itu sedang marak terjadi di Lampung.

Beliau juga berpendapat bahwa keberadaan tokoh masyarakat pada era ini sudah banyak ditinggalkan. Padahal menurut beliau, jika keberadaan tokoh masyarakat tersebut kembali dikedepankan kembali, dan tradisi terus dihidupkan maka akan ada tokoh yang dituakan dalam suatu lingkungan masyarakat. Dengan begitu konflik sosial diharapkan dapat terminimalisir, karena segala sesuatunya dapat dimusyawarahkan (Rogers, 1983).

Anjau Silau dan rembuk pekon yang diadopsi kedalam kinerja Kepolisian Daerah Provinsi Lampung merupakan bentuk upaya preventif untuk mengantisipasi kejahatan dan pelanggaran hukum. Sebagaimana dikemukakan oleh Baharuddin Lopa, salah satu Jaksa Agung terbaik yang pernah dimiliki bangsa ini, mengemukakan pikirannya bahwa upaya menanggulangi kejahatan dapat dilakukan dengan langkahlangkah preventif, yaitu a) peningkatan kesejahteraan rakyat untuk mengurangi pengangguran, yang dengan sendirinya akan mengurangi kejahatan. b) Memperbaiki sistem administrasi dan pengawasan untuk mencegah terjadinya penyimpanganpenyimpangan. c) Peningkatan penyuluhan hukum untu memeratakan kesadaran hukum rakyat. d) Menambah personel kepolisian dan personel penegak hukum lainnya untuk lebih meningkatkan tindakan represif maupun preventif. e) Meningkatkan ketangguhan moral serta professionalisme bagi para pelaksana penegak hukum (Baharuddin Lopa,
2001 dalam Lampung Post, Bhayangkara Lampung Melintas Badai, 2016).

Jika diperhatikan, rembuk pekon dan anjau silau memang sekilas memiliki arti yang sama. Perbedaan rembuk pekon dengan anjau silau ialah jika dalam rembuk pekon aparat yang mendatangi masyarakat, tetapi dalam anjau silau aparat keamanan dan masyarakat saling berkunjung dalam suasana yang menjunjung tinggi nilai-nilai kearifan lokal. Keduanya merupakan nilai kearifan lokal Lampung sebagai upaya untuk menekan angka kriminalitas di Lampung dengan menggunakan pendekatan budaya.

\section{Tahap Penilaian (Evaluation)}

Menurut Rogers (1983), pada tahap penilaian merupakan tahapan dimana mulai munculnya rasa menimbang-nimbang untuk kemungkinan melaksanakan adopsi. Sama halnya dengan tahap adopsi nilai kearifan lokal rembuk pekon oleh Brigjen Pol Heru Winarko, beliau pada tahap ini juga merasa memikirkan untuk melaksanakan adopsi rembuk pekon pada kinerja Kepolisian Daerah Provinsi Lampung. Beliau meyakini bahwa dengan rembuk pekon dapat mengatasi permasalahan sosial karena memiliki kemampuan deteksi dini yang dapat mencegah suatu masalah terjadi dengan memusyawarahkannya.

Tahap penilaian Brigjen Pol Heru Winarko mengadopsi nilai kearifan lokal rembuk pekon merupakan tahap dimana beliau mempertimbangkan kemungkinan untuk mengadopsi rembuk pekon tersebut. Beliau meninjau kembali manfaat yang didapat jika mengadopsi nilai kearifan lokal rembuk pekon. Yaitu dengan memusyawarahkan suatu permasalahan agar permasalahan tersebut tidak melebar.

Kemudian pada tahap penilaian dalam adopsi nilai kearifan lokal anjau silau oleh Brigjen Pol Edward Syah Pernong, beliau 
melakukan tahap ini dengan mendiskusikan rencana pengadopsian anjau silau ke dalam kinerja Kepolisian Daerah Provinsi Lampung bersama dengan Brigjen Pol Ike Edwin yaitu sepupunya dalam Kerajaan Lampung Skala Brak. Dalam kegiatan berembuk antara keduanya memiliki misi yang sama yaitu menekankan kearifan lokal dan hubungan baik antara masyarakat. Kegiatan menimbang-nimbang tersebut sama halnya seperti Rogers pada tahap penilaian.

Pada tahap penilaian pada adopsi nilai kearifan lokal falsafah piil pessenggiri, Brigjen Pol Ike Edwin memiliki penilaian atas keyakinannya dengan falsafah piil pessenggiri dapat merubah pandangan buruk masyarakat menjadi lebih baik seperti yang diharapkannya. Peneliti melihat niat yang dilakukan oleh beliau sebagai putra Lampung juga dalam rangka menjunjung tinggi budaya yang menurutnya baik dan patut untuk dijalankan dalam Kepolisian Daerah Provinsi Lampung.

\section{Tahap Mencoba (Trial)}

Dalam tahapan ini jika keterangan sudah lengkap, minat untuk meniru besar, dan jika ternyata hasil penilaiannya positif, maka dimulai usaha mencoba hal baru yang sudah diketahuinya. Pada penelitian ini, dalam masa kepemimpinan Brigjen Pol Heru Winarko pada adopsi nilai kearifan lokal rembuk pekon, yaitu dengan membuat nota kesepahaman antara tokoh-tokoh yang berpengaruh di Lampung. Yaitu antara Brigjen Pol Heru Winarko, Gubernur Lampung pada saat itu Sjachroedin ZP, dan Komandan Korem Garuda Hitam Kolonel (Czi) Amalsyah Tarmizi dalam Forum Komunikasi Pimpinan Daerah Lampung. Dalam nota kesepahaman tersebut menyepakati pentingnya rembuk pekon sebagai wadah untuk menanggulangi dan mengatasi konflik horizontal di Lampung.
Peneliti menilai tahap mencoba ini merupakan tahapan bagi Brigjen Pol Heru Winarko untuk menunjukkan bahwa program yang kemudian akan dilaksanakannya yaitu rembuk pekon dapat diterima masyarakat dan mendapatkan respon positif di semua kalangan. Dengan adanya tahapan ini akan semakin meyakinkan pengadopsi yaitu Brigjen Pol Heru Winarko untuk langsung melaksanakan adopsi nilai kearifan lokal rembuk pekon dalam kinerja Kepolisian Daerah Provinsi Lampung bersamaan dengan pembuatan nota kesepahaman tersebut.

Tahap mencoba dan tahap adopsi seringkali dilakukan bersamaan karena dengan keyakinan yang baik bahwa adopsi akan menjadi sesuatu yang berhasil maka akan lebih cepat tahap adopsi dilakukan. Brigjen Pol Edward Syah Pernong dalam tahapan ini dirasa telah sangat yakin dengan semua pertimbangan yang telah dilakukan sebelumnya.

Kemudian pada tahap mencoba oleh Brigjen Pol Ike Edwin dalam mengadopsi nilai kearifan lokal falsafah piil pessenggiri, beliau mulai mencoba untuk mengadopsi nilai kearifan lokal Lampung berupa slogan PIIL (Profesional, Integritas, Iman dan Law enforcement) yang diangkat dari falsafah piil pessenggiri kedalam kinerja Kepolisian Daerah Provinsi Lampung dengan menanyakan kepada rekan-rekannya mengenai kecocokan falsafah piil pessenggiri jika dijadikan slogan Kepolisian Daerah Provinsi Lampung. Kemudian beliau mendapatkan respon positif dari pertanyaan yang beliau ajukan kepada orang-orang tersebut. Respon tersebut membuat keyakinan Brigjen Pol Ike Edwin untuk segera melaksanakan adopsi nilai kearifan lokal falsafah piil pessenggiri yang dituangkan dalam tagline PIIL ke dalam kinerja Kepolisian Daerah Provinsi Lampung.

Peneliti menilai tahapan ini sangat penting untuk kelangsungan adopsi tersebut. 
Sehingga apabila ada respon negatif, Kapolda dapat segera mengoreksi pilihannya untuk mengadopsi nilai kearifan lokal Lampung tersebut.

\section{Tahap Adopsi (Adoption)}

Tahap adopsi nilai kearifan lokal anjau silau oleh Brigjen Pol Edward Syah Pernong dimulai bersamaan dengan tahap mencoba dan beliau berkeyakinan akan berhasil. Lalu adopsi nilai kearifan lokal falsafah piil pessenggiri dalam tagline PIIL oleh Brigjen Pol Ike Edwin juga dilakukan pada tahap adopsi ini dengan keyakinan yang sama yaitu akan berhasil merubah pandangan buruk masyarakat terhadap kepolisian.

Jadi, keseluruhan dari nilai kearifan lokal yang diadopsi oleh Brigjen Pol Heru Winarko, Brigjen Pol Edward Syah Pernong, dan Brigjen Pol Ike Edwin yaitu kearifan lokal Lampung rembuk pekon, anjau silau, dan falsafah piil pessenggiri. Dengan hadirnya program anjau silau yang merupakan penajaman program dari Brigjen Pol Heru Winarko yaitu rembuk pekon, yang bertujuan sebagai langkah meminimalkan potensi konfilik yang dapat terjadi diberbagai daerah Provinsi Lampung. Dengan anjau silau, kegiatan berkunjung ini dapat menghasilkan diskusi tentang kabar dan gagasan permasalahan yang ada di suatu daerah yang dikunjungi tersebut.

Kemudian dengan adanya slogan PIIL yang merupakan singkatan dari Profesional, Integritas, Iman dan Law enforcement diangkat dari falsafah Lampung yaitu piil pessenggiri yang bermakna harga diri, perilaku dan sikap hidup diharapkan dapat mengubah citra buruk kepolisian terhadap masyarakat. Para pemimpin pada masa kepemimpinannya masing-masing berkeyakinan bahwa dengan pendekatan budaya, segenap permasalahan yang ada di Lampung dapat teratasi.

Tahap adopsi merupakan tahap akhir dari tahapan-tahapan di atas. Menurut penulis, dengan adanya tahapan mulai dari tahap kesadaran sampai ke tahap adopsi sudah cukup efektif untuk menciptakan adopsi yang dapat berjalan sesuai harapan dari masingmasing Kapolda tersebut. Karena, dari tahapan di atas telah mencakup segala pertimbangan yang matang yang kemudian menghasilkan inovasi baru dalam Polda Lampung untuk mengoptimalkan kinerjanya. Terlihat bahwa adopsi nilai kearifan lokal Lampung ke dalam kinerja Kepolisian Daerah Provinsi Lampung berdasarkan pemikiran yang matang untuk mengeluarkan program Kapolda. Sehingga menghasilkan program yang mengoptimal-kan kinerja kepolisian baik dengan langkah preventif dan dengan langkah penyelesaian yang bersifat kekeluargaan. Program rembuk pekon, anjau silau, dan slogan PIIL merupakan hasil adopsi nilai kearifan lokal Lampung sebagai upaya Kepolisian Daerah Provinsi Lampung untuk mengamankan Provinsi Lampung.

\section{Kinerja Kepolisian Daerah Provinsi Lampung Dengan Adanya Adopsi Nilai Kearifan Lokal}

Kepolisian Daerah Provinsi Lampung mengadopsi nilai kearifan lokal Lampung ke dalam kinerja mereka untuk menjalankan tujuannya yaitu meminimalkan potensi konflik secara efektif. Dengan melalui pendekatan budaya tersebut, kinerja Kepolisian Daerah Provinsi Lampung diharapkan dapat optimal. Kinerja Kepolisian Daerah Provinsi Lampung yang menggunakan adopsi nilai kearifan lokal Lampung yaitu dalam program rembuk pekon, anjau silau, dan PIIL dari falsafah Lampung piil pessenggiri.

Kepolisian Daerah Provinsi Lampung mengadopsi nilai kearifan lokal Lampung ke dalam kinerja mereka untuk menjalankan tujuannya yaitu meminimalkan potensi konflik secara efektif. Dengan melalui pendekatan budaya tersebut, kinerja 


\section{Penilaian Performansi Berdasarkan Hasil (Result-based Performance Evaluation)}

Robbins menyebutkan tipe kriteria performansi ini merumuskan performansi pekerjaan berdasarkan pencapain tujuan organisasi, atau mengukur hasil-hasil akhir (end result). Sasaran bisa ditetapkan oleh manajemen atau oleh kelompok kerja, tetapi jika menginginkan agar para karyawan meningkatkan produktivitas mereka, maka penetapan sasaran secara partisipatif, dengan melibatkan para karyawan, akan jauh berdampak positif terhadap peningkatan produktivitas organisasi. Para karyawan akan cenderung menerima tujuan-tujuan itu sebagai tujuan mereka sendiri, dan merasa lebih bertanggung jawab untuk dan selama pelaksanaan pencapaian tujuan-tujuan (Robbins, 2001).

Penilaian ini dapat dilihat dari hasil yang telah dicapai dari tujuan Kepolisian Daerah Provinsi Lampung. Menjaga rasa aman dan nyaman merupakan salah satu kewajiban Kepolisian dalam pengabdiannya kepada Negara Kesatuan Republik Indonesia (NKRI). Ditengah-tengah keadaan Daerah Provinsi Lampung dengan kondisi keamanan yang buruk, pihak Kepolisian Daerah Provinsi Lampung berupaya meminimalisir angka kriminalitas salah satunya dengan program anjau silau. Program tersebut dapat dikatakan berhasil karena angka kriminalitas yang ada di Provinsi Lampung menurun.

Dari data penyelesaian masalah melalui mediasi rembuk pekon tercatat pada tahun 2015 terdapat 5933 masalah dan pada tahun 2016 terdapat 6714 masalah yang diselesaikan melalui rembuk pekon. Penilaian kinerja kepolisian berdasarkan data penyelesaian masalah melalui rembuk pekon yang telah dicapai tersebut sangat mengacu kepada tujuan Kepolisian Daerah Lampung yaitu memaksimalkan kinerja Kepolisian Daerah Provinsi Lampung. dan dibuktikan dari data tersebut, dapat disimpulkan bahwa hasil dari program yang mengadopsi nilai kearifan lokal sudah cukup optimal.

Dengan adanya penurunan angka kriminalitas yang ada di Provinsi Lampung dan dengan kepuasan masyarakat akan kinerja yang diadopsi dari nilai kearifan lokal Lampung mencerminkan keberhasilan adopsi nilai kearifan lokal dalam kinerja Kepolisian Daerah Provinsi Lampung. Namun, hal tersebut harus tetap ditingkatkan lagi. Mengingat angka kriminalitas belum sepenuhnya nihil. Pihak kepolisian harus tetap berupaya menekan angka kriminalitas yang ada di Lampung.

\section{Penilaian Performansi Berdasarkan Perilaku (Behavior-based Performance Evaluation)}

Untuk mencapai tujuan dari Kepolisian sebagai pengaman dan pengayom masyarakat, Kepolisian Daerah Provinsi Lampung menggunakan pendekatan budaya dalam kinerjanya. Pendekatan budaya tersebut dilakukan sebagai bentuk upaya pemecahan masalah dan langkah preventif dari Kepolisian.

Kinerja Kepolisian Daerah Provinsi Lampung jika dinilai berdasarkan proses dari pencapaian tujuan Polda Lampung sudah cenderung baik. Dalam program yang mengadopsi nilai kearifan lokal Lampung seperti rembuk pekon dan anjau silau berjalan dengan sangat baik. Sasaran kegiatan anjau silau adalah orang-orang yang memiliki pengaruh di masyarakat, meliputi pemimpin masyarakat formal seperti jabatan negara, pemerintah atau pimpinan instansi, sivitas akademi organisasi politik, pemilik dan pemimpin perusahaan, serta pemimpin lembaga sosial. Lalu, pemimpin masyarakat tidak formal yang merupakan orang-orang tertentu dalam masyarakat yang berpengaruh karena disegani, diteladani, dihormati, baik karena sifatnya yang luhur maupun kemampuan pribadinya, status dan perannya dalam masyarakat, seperti tokoh masyarakat, 
tokoh agama, tokoh adat, dan tokoh pemuda. Sementara pelaksana kegiatan anjau silau adalah kapolsek dan para kanit di polsek, kapolres dan para kabag, kasat di polres, kapolda dan para pejabat utama di Polda, serta personel Polda Lampung yang di tunjuk berdasarkan surat perintah kapolda.

Sedangkan mekanisme pelaksanaannya adalah melakukan pendataan orang-orang yang mem pengaruh di masyarakat, baik secara formal maupun tidak formal, menentukan jadwal anjau silau hari tokoh), menentukan personel yang melaksanakan anjau silau, melaporkan pelaksanaan kegiatan anjau silau kepada Kapolda Lampung sesuai format yang telah ditetapkan (satu minggu sekali). Tempat pelaksanaan kegiatan anjau silau adalah rumah atau tempat kediaman, kantor dari pimpinan masyarakat formal maupun pimpinan masyarakat tidak formal.

Hasil yang ingin dicapai dalam pelaksanaan kegiatan anjau silau ini adalah tumbuh kembangnya kedekatan emosional antara personel maupun pimpinan Polri, khususnya Polda Lampung, dan masyarakat maupun kelompok masyarakat di Lampung. Lalu, terekam dan terakomodasinya aspirasi masyarakat dari bawah maupun atas. Terbitnya kebijakan Polri, khususnya Polda Lampung, yang didukung oleh masyarakat di masing-masing wilayah di Lampung. Terantisipasi dan teredamnya konflik sosial, horizontal, maupun vertikal sehingga pada akhirnya anjau silau juga membentuk kedekatan emosional antarpersonel maupun pimpinan Polri, khususnya Polda Lampung, dengan masyarakat maupun kelompok masyarakat.

Dengan demikian, early warning system dalam pencegahan konflik akan berjalan dengan baik. Pendekatan budaya menjadi cara yang optimal dalam menanggulangi masalah kriminalitas di Lampung dan bahkan sebagai pencegahannya. Langkah tersebut dilakukan oleh aparat kepolisian dari program tersebut juga sudah terlihat berjalan dengan baik dan menuai banyak respon positif dari masyarakat Lampung.

\section{Penilaian Performansi Berdasarkan Judgement (Judgement-based Performance Evaluation)}

Tipe kriteria performansi yang menilai dan/atau mengevaluasi performansi kerja karyawan berdasarkan deskripsi perilaku yang spesifik, quantity of work, job knowledge, cooperation, initiative, dependability, personal qualities, dan yang sejenis lainnya. Programprogram yang telah diberlakukan baik oleh Kapolda Lampung yang sekarang, maupun Kapolda Lampung yang sebelum-sebelumnya merupakan bentuk upaya yang dilakukan oleh Kepolisian Daerah Lampung untuk memberantas kejahatan dan memberikan rasa aman kepada masyarakat.

Upaya yang dilakukan mantan Kapolda Lampung dengan sentuhan adopsi kearifan lokal Lampung, piil pessenggiri merupakan upaya yang sangat baik untuk mengubah citra kepolisian dimata masyarakat Lampung. Namun seiring berjalannya program-program tersebut, masih seringkali ditemukan oknumoknum kepolisian yang bertindak tidak sepatutnya. Seperti contohnya dengan banyaknya laporan oleh masyarakat Lampung yang diterima mantan Kapolda Lampung Brigjen Pol Ike Edwin tentang perilaku anggota kepolisian yang berperilaku tidak baik.

Kinerja Kepolisian Daerah Provinsi Lampung dengan adopsi nilai kearifan lokal Lampung, berdasarkan segi perilaku yang spesifik dari tiap-tiap anggota Kepolisian sudah cukup baik. Dengan falsafah piil pessenggiri yang merupakan akar dari slogan PIIL diformulasikan dengan sangat baik dan implementasi yang sudah cukup baik walaupun masih ditemui oknum-oknum kepolisian yang tidak bekerja sesuai dengan 
slogan kepolisian Lampung yaitu PIIL tersebut. Dibutuhkan pengawasan yang lebih agar tindakan oknum-oknum kepolisian yang menyimpang dapat segera hilang sehingga kepolisian Lampung dapat bekerja dengan optimal.

\section{PENUTUP}

Dalam proses adopsi nilai kearifan lokal ke dalam kinerja Kepolisian Daerah Provinsi Lampung, terdapat lima tahapan adopsi. Mulai dari 1) tahap kesadaran, dimana Kapolda mulai menyadari adanya sesuatu yang baik dari nilai kearifan lokal Lampung untuk disisipkan ke dalam kinerja Polda Lampung. 2) tahap minat, yaitu Kapolda mencari keterangan tentang hal tersebut dan menetapkan nilai kearifan lokal yang akan digunakan. 3) tahap penilaian, dimana Kapolda mulai menimbang-nimbang untuk melaksana-kan adopsi tersebut. 4) tahap mencoba, yaitu tahapan memulai usaha mencoba mengadopsi nilai kearifan lokal tersebut.

Sampai ke tahap adopsi dimana Kapolda benar-benar melaksanakan adopsi tersebut ke dalam kinerja Kepolisian Daerah Provinsi Lampung dengan berkeyakinan akan berhasil. Kelima tahapan tersebut telah terlaksanakan seluruhnya dengan baik pertama kali oleh Kapolda Lampung Brigjen Pol Heru Winarko, kemudian diteruskan dan ditambahkan lagi adopsi nilai kearifan lokalnya oleh Brigjen Pol Edward Syah Pernong, dan Brigjen Pol Ike Edwin. Selanjutnya terus dilanjutkan sampai dengan kepemimpinan Kapolda Lampung yang sekarang yaitu Brigjen Pol Sudjarno.Nilai kearifan lokal Lampung yang diadopsi berupa falsafah Lampung piil pessenggiri, rembuk pekon, dan juga anjau silau.

Adopsi nilai kearifan lokal tersebut dilakukan dalam rangka sebagai upaya untuk mengoptimalkan kinerja dari Kepolisian
Daerah Provinsi Lampung melalui pendekatan budaya.

Kinerja Kepolisian Daerah Provinsi Lampung dalam penelitian ini dinilai menggunakan metode penilaian kinerja yaitu: Pertama, penilaian performansi berdasarkan hasil (result-based performance evaluation), yang dapat dinilai bahwa kinerja kepolisian berhasil menurunkan angka kriminalitas di Provinsi Lampung.

Kedua, penilaian performansi berdasarkan perilaku (behavior based performance evaluation), dapat diambil kesimpulan bahwa pendekatan budaya menjadi cara yang optimal dalam menanggulangi masalah kriminalitas di Lampung dan bahkan sebagai pencegahannya.

Ketiga adalah penilaian performansi berdasarkan judgement (judgement-based performance evaluation), berdasarkan segi perilaku yang spesifik dari tiap-tiap anggota kepolisian Dengan falsafah piil pessenggiri yang merupakan akar dari slogan PIIL telah diformulasikan dengan sangat baik dan implementasinya sudah cukup baik, walaupun masih ditemui oknum-oknum kepolisian yang tidak bekerja sesuai dengan slogan PIIL. Hasil dari penilaian kinerja dengan adanya adopsi nilai kearifan lokal Lampung didalamnya yaitu cukup baik dan cukup dapat mengatasi kriminalitas di Daerah Provinsi Lampung.

Adapun beberapa saran yang dapat dirumuskan antara lain:

1. Sebaiknya program dengan adopsi nilai kearifan lokal Lampung di dalamnya terus dilanjutkan walaupun dengan adanya pergantian Kapolda Lampung. Mengingat bahwa program tersebut dapat dikatakan cukup berhasil dan respon dari masyarakat juga sangat positif.

2. Sebaiknya dalam program anjau silau dibuat evaluasi misalkan berjenjang per triwulan atau dapat ditentukan sesuai kebutuhan. Jadi hasil dari anjau silau dapat 
lebih terlihat dan menjadi acuan untuk terus meningkatkan kinerja kepolisian.

3. Sebaiknya dilakukan pengawasan yang lebih ketat agar oknum-oknum kepolisian yang masih bertindak tidak baik dapat segera hilang di Daerah Lampung.

4. Sebaiknya Kapolda ataupun pimpinan dari masing-masing jabatan terus melakukan penyuluhan tentang slogan PIIL agar anggota kepolisian dapat lebih memahami makna dari slogan tersebut dan dapat mengimplementasikannya.

\section{DAFTAR PUSTAKA}

. (2016). Bhayangkara Lampung Melintas

Badai. Bandarlampung: Lampung Post.

Keraf, A. (2010). Etika Lingkungan Hidup. Jakarta: Penerbit Buku Kompas.

Mardikanto, T. (1993). Penyuluhan Pembangunan Pertanian. Surakarta: Sebelas Maret University Press UNS.

Robbins, S. (. (1983). Diffusion of Innovation, Third Edition. New York: Free Press.

Samsudin, U. (1982). Dasar-Dasar Penyuluhan dan Modernisasi Pertanian. Bandung: Binacipta.

Suryabrata, S. (1998). Psikologi Kepribadian. Jakarta: PT Raja Grafindo Persada.

Suswanto, B. H. (2015). Model Community Development Sebagai Strategi Pemberdayaan Berbasis Kearifan Lokal. Jurnal Review Politik, Vol. 3 (2) , 298-312.

Sutrisno, E. (2011). Budaya Organisas. Jakarta: Kencana.

Suwardani, N. (2015). Pewarisan Nilai-nilai Kearifan Lokal untuk Memproteksi
Masyarakat Bali dari Dampak Negatif Globalisasi. Journal Of Bali Studies, Vol. 5 (2) .

Yulianto, M. N., \& Hutagalung, S. S. (2017). Adoption of Local Values for Bureaucratic Reform in Lampung Province. 6th Global Conference on Business and Social Sciences on "Contemporary Issues in Business and Social Sciences Research" (CIBSR - 2017) (pp. 98107). Bangkok: Global Academy of Training and Research (GATR). 